Article

\title{
Ruminal Fermentation, Growth Rate and Methane Production in Sheep Fed Diets Including White Clover, Soybean Meal or Porphyra sp.
}

\author{
Vibeke Lind ${ }^{1, *(\mathbb{D}}$, Martin R. Weisbjerg ${ }^{2}{ }^{\oplus}$, Grete M. Jørgensen ${ }^{1}{ }^{(}$, Júlia E. Fernandez-Yepes ${ }^{3}$, \\ Lesly Arbesú ${ }^{3}$ and Eduarda Molina-Alcaide ${ }^{3}$ (i) \\ 1 Norwegian Institute of Bioeconomy Research (NIBIO), PB 115, N-1431 Aas, Norway; \\ grete.jorgensen@nibio.no \\ 2 Department of Animal Science, Aarhus University, AU Foulum, Blichers Allé 20, 8830 Tjele, Denmark; \\ martin.weisbjerg@anis.au.dk \\ 3 Estación Experimental del Zaidin (Consejo Superior de Investigaciones Científicas), Profesor Albareda, 1, \\ 18008 Granada, Spain; julia.fernandez@eez.csic.es (J.E.F.-Y.); lesly.arbesu@eez.csic.es (L.A.); \\ molina@eez.csic.es (E.M.-A.) \\ * Correspondence: vibeke.lind@nibio.no; Tel.: +47-93499436
}

Received: 5 December 2019; Accepted: 31 December 2019; Published: 2 January 2020

check for updates

Simple Summary: In ruminant feeding, the use of diets containing seaweeds could be a valuable alternative to conventional diets. The objective of this work was to investigate the ruminal fermentation, growth rate and methane production in sheep fed a diet including Porphyra sp. compared with diets including clover silage or soybean meal. Including Porphyra sp. had little impact on ruminal fermentation and methane production both in vitro and in vivo. Lambs fed Porphyra sp. had a similar growth rate to those fed a diet including soybean meal, confirming previous in vitro and in situ observations on the high-quality protein of Porphyra sp. in ruminant feed.

\begin{abstract}
The aim of the present work was to investigate the potential of Porphyra sp. as an alternative source of protein to soybean meal in diets for sheep. Our experimental treatments included a control diet (CON) based on grass silage and crushed oats and three diets containing protein supplements, clover silage (CLO), soybean meal (SOY) or Porphyra sp. (POR) to increase dietary crude protein concentrations. We studied its effects on rumen fermentation, growth rate and methane emissions. Ruminal fermentation characteristics, kinetics of gas production and methane production were studied in vitro by using batch cultures inoculated with rumen inoculum from sheep. There were no differences among diets in total volatile fatty acids (VFA) production or in the VFA profile in vitro. Across treatments, we measured no differences in methane production either in vitro or in vivo, and we saw no noticeable antimethanogenic effect of Porphyra sp. The present in vivo trial with lambs showed no differences in average daily weight gain when fed diets including Porphyra sp. or soybean meal diets (250 and $254 \mathrm{~g} / \mathrm{d}$, respectively). We conclude that Porphyra sp. has a protein value similar to high-quality protein sources like soybean meal.
\end{abstract}

Keywords: Macroalgae; lamb; ewe; in vitro; in vivo; performance; seaweed

\section{Introduction}

The increased demand for food to provide for a growing global population, estimated to reach more than 9 billion by 2050 [1], is a challenge for animal production systems. Prohibition of the use of animal and fish protein subsequent to the BSE crisis in the 1990s, along with structural changes in cereal production at the expense of grain-legumes [2], produced a gap in the supply of protein to ruminants. 
Additional protein was needed and imported soybean meal seemed to be the most suitable. Norwegian cereal and seed production do not meet the feed demands for increased animal production. Thus, more than $90 \%$ of the protein and $40 \%$ of all the ingredients in Norwegian commercial concentrates are imported [3]. In addition, since 1996, the import and use of GMO-ingredients are prohibited [4]. Therefore, in Norway, a focus on locally produced concentrates covering the demand for protein sources is essential.

Traditionally, seaweed has been used in Norwegian coastal communities as a feed supplement, especially when there was shortage of forage [5]. Due to geography, environment and the characteristics of aquaculture production, conditions along the Norwegian coast are well suited to produce seaweed.

The protein concentration is high in Rhodophytal (red) and Chlorophyta (green) seaweed species (10-47\% of dry matter (DM)) compared to that in Phaeophyta (brown) seaweed species (3-15\% of DM) [6-9]. For the red seaweed Porphyra sp., the protein concentration may be as high as $47 \%$ of DM in the spring, which could make it relevant as a substitute for soybean meal [7]. In general, the amino acid composition of Porphyra sp., is similar to proteins from soybean and eggs [9-11]. Palatability when feeding seaweeds to ruminants has been mentioned by, e.g., Roque et al. [12] and Özkan-Gülzari et al. [13] and dealt with by adding water or molasses.

It has long been accepted that the feeding value of protein rich legumes is often greater than that of grasses fed to ruminants [14]. This is because of their more rapid particle breakdown, faster rumen fermentation, lower mean rumen retention time and, consequently, greater voluntary feed intake [15]. White clover (Trifolium repens) contains from $17 \%$ to $33 \%$ protein, depending on its stage of maturity, and is an important source of protein.

Enteric emissions of methane $\left(\mathrm{CH}_{4}\right)$ by ruminants, arise primarily from the fermentation of feed in the rumen. Methane is an important greenhouse gas and represents an energy loss from the animal that results in reduced productivity. Because methane emissions are influenced by type of feed, ruminant nutritionists have focused studies on dietary strategies that can reduce $\mathrm{CH}_{4}$ emissions [16-18].

In vitro and in situ techniques are used in animal nutrition research as they are less expensive, time-consuming and laborious compared to in vivo experiments. There are some in vitro and in situ studies investigating the nutritive value of seaweeds $[7-9,19]$ but, to our knowledge, very few in vivo experiments have been performed using seaweed as a protein source for ruminants [12,20,21]. Also, we have no knowledge of in vivo experiments including Porphyra sp. to investigate enteric $\mathrm{CH}_{4}$ production or growth rate in ruminants. Therefore, Porphyra sp., the most promising seaweed of eight Norwegian species tested in vitro and in situ by Tayyab et al. [7], Molina-Alcaide et al. [8] and Gaillard et al. [9], was used in the present work. In this study, we compared the effect of dietary protein source on animals' ruminal fermentation, growth rate and $\mathrm{CH}_{4}$ production both in vitro and in vivo. In particular, our aim was to assess the efficacy of Porphyra sp. as a protein source when compared with more traditional sources such as clover silage and soybean. We hypothesized that Porphyra sp. can substitute soybean meal or clover silage as a protein source in sheep diets without affecting ruminal fermentation, growth rate or enteric methane production.

\section{Materials and Methods}

\subsection{Diet Ingredients}

We used the following ingredients in our diets: first cut grass silage (Bromus inermis, Poa pratensis, Festuca pratensis), first cut white clover (Trifolium repens Litago) silage, crushed oats, soybean meal and the seaweed Porphyra sp. (CoDO International limited Yantai City, China), in addition to a standard mineral-vitamin mixture (PLUSS sau pellets, Felleskjøpet Agri, Gardermoen, Norway). The chemical composition is shown in Table 1 . Both grass and white clover were wilted for one day after cutting before packing in round bales without any additives. The fermentation quality of the silages was good ( $\mathrm{pH} 4.2$ for both silages) and levels of lactic, acetic, propionic and butyric acid were within normal ranges according to Eurofins [22]. Porphyra sp. is not yet cultivated in Norway and therefore manual 
collection for in vivo trials would be too labor intensive and time consuming. Chemical analysis of the purchased Porphyra was compared to Porphyra sp. collected from the Norwegian coast and found to be similar (35.5 and $34.6 \mathrm{~g} / 100 \mathrm{~g}$ crude protein, respectively). Porphyra sp. was purchased in the form of powder (dried and milled) and used without further processing. The product was stored in a clean and dry place until use.

Table 1. Average chemical composition ( $\mathrm{g} / \mathrm{kg} \mathrm{DM})$ of diet ingredients.

\begin{tabular}{cccccc}
\hline Item. & Grass Silage & $\begin{array}{c}\text { White Clover } \\
\text { Silage }\end{array}$ & Crushed Oats & $\begin{array}{c}\text { Soybean Meal } \\
\text { Pellets }\end{array}$ & Porphyra sp. \\
\hline DM, g/kg fresh & 383 & 352 & 943 & 932 & 947 \\
Ash & 60.9 & 86.8 & 28.0 & 60.0 & 21.6 \\
Crude protein & 137 & 137 & 235 & 545 & 371 \\
NDF & 521 & 433 & 115 & 120 & 58 \\
DOM $^{1}$ & 707 & 721 & 972 & 929 & 898 \\
FU $^{2} / \mathrm{kg} \mathrm{DM}^{1}$ & 0.83 & 0.83 & 1.09 & 1.10 & 0.80 \\
\hline \multicolumn{2}{c}{ DOM: in vitro Digestible organic matter; ${ }^{2}$ FU Scandinavian Feed Unit: 1 FU = 7.89 MJ net energy. }
\end{tabular}

\subsection{Diets}

A control diet $(\mathrm{CON})$ based on grass silage and crushed oats was compared with three experimental diets with an additional protein source of either clover silage (CLO) or soybean meal (SOY) or Porphyra sp. (POR). All diets included the vitamin-mineral mixture. The ingredients and chemical compositions of the diets are shown in Table 2. The proportion of white clover in the CLO diet was $59 \%$ while the proportion of the protein sources soybean meal and Porphyra sp., in the SOY and POR diets, respectively, constituted about $10 \%$ of the diet.

The DM content of the four diets was around $88 \%$ and the crude protein content varied from $111 \mathrm{~g} / \mathrm{kg}$ DM (CON) to 125, 137 and $126 \mathrm{~g} / \mathrm{kg}$ DM for CLO, SOY and POR diets, respectively. Diets with protein enrichment (CLO, SOY and POR) were composed to be isoenergetic and isoproteinic.

Table 2. Ingredients ( $\mathrm{g} / \mathrm{kg}$ fresh matter) and chemical composition $(\mathrm{g} / \mathrm{kg} \mathrm{DM})$ of control and experimental diets.

\begin{tabular}{ccccc}
\hline Diet & CON & CLO & SOY & POR \\
\hline Ingredients & & & & \\
Grass silage & 922 & 352 & 835 & 833 \\
Crushed oats & 62 & 46 & 55 & 56 \\
Clover silage & & 590 & & \\
Soybean meal & & 96 & \\
Porphyra sp. & & & & 97 \\
Mineral-vitamin mixture & 16 & 12 & 14 & 14 \\
Chemical composition of dry matter & & & & \\
Organic matter & 918 & 927 & 933 & 927 \\
Crude protein & 111 & 125 & 137 & 126 \\
Ether extract & 37.2 & 36.8 & 36.5 & 34.5 \\
Neutral detergent fiber & 511 & 516 & 491 & 502 \\
Acid detergent fiber & 274 & 274 & 248 & 270 \\
Acid detergent lignin & 25.6 & 33.8 & 23.2 & 22.8 \\
Gross energy, MJ/kg DM & 17.2 & 16.7 & 17.3 & 17.0 \\
Protein bound condensed tannins & 0.158 & 0.281 & 0.239 & 0.224 \\
Free condensed tannins & 0.307 & 0.294 & 0.296 & 0.240 \\
Fibre bound condensed tannins & 9.44 & 8.43 & 8.56 & 10.26 \\
Total condensed tannins & 9.91 & 9.01 & 9.10 & 10.7 \\
\hline
\end{tabular}

${ }^{1}$ CON: control diet; CLO: diet including clover silage; SOY: diet including soybean meal; POR: diet including Porphyra sp. 


\subsection{In Vitro Trial}

Three adult, dry, non-pregnant and rumen-fistulated Segureña sheep (Mean \pm SD; $51.9 \pm 2.75 \mathrm{~kg}$ body weight $(\mathrm{BW})$ ) were used as inoculum donors for the in vitro incubations. Animals were placed in individual boxes and fed alfalfa hay supplied to meet energy maintenance requirements [23]. Animals had free access to water, were cared for and handled by trained personnel in accordance with the Spanish guidelines for experimental animal protection (Royal Decree 53/2013 of February 1st on the protection of animals used for experimentation or other scientific purposes). All the experimental procedures were approved by the Animal Welfare Committee at the Estación Experimental del Zaidin (CSIC, Spain).

The batch culture procedure was used to study ruminal fermentation characteristics, $\mathrm{CH}_{4}$ emissions and the kinetics of gas production from control and experimental diets. The experimental procedure was based on the Theodorou et al. [24] protocol with some modifications. Rumen content from each of the three sheep was collected before the morning feeding, pooled and immediately taken to the laboratory into thermal flasks. Rumen contents were strained through four layers of cheesecloth and mixed with a buffer solution [25] in a 1:4 ratio (vol/vol) at $39{ }^{\circ} \mathrm{C}$ under continuous flushing with $\mathrm{CO}_{2}$. The time required from rumen content collection to inoculation of bottles was $<30 \mathrm{~min}$. Control and experimental diets were mixed in rations similar to the in vivo trial. Samples of the diets were ground $(1 \mathrm{~mm})$ before analyses for chemical composition and used as substrates in the in vitro runs. Three identical $72 \mathrm{~h}$ incubation runs were carried out over three consecutive weeks. Four bottles per diet and four bottles without added diet (blanks) were incubated in each run. Blanks were used to correct the gas production values for gas release from endogenous substrates. Samples (0.500 g) of diets were carefully weighed into $120 \mathrm{~mL}$ bottles, and $60 \mathrm{~mL}$ of the buffered rumen fluid was anaerobically added into each bottle. Bottles were sealed with butyl rubber stoppers and aluminum caps and incubated at $39^{\circ} \mathrm{C}$ in a water bath. In two of the four bottles for each diet and two blanks, pressure and gas volume were measured at 2, 4, 6, 8, 12, 24, 48 and $72 \mathrm{~h}$ of incubation using a Wide Range Pressure Meter (Sper Scientific LTD, Scottsdale, AZ, USA) and a glass-calibrated syringe (Ruthe ${ }^{\circledR}$, Normax, Marinha Grande, Portugal), respectively. In the remaining two bottles of each sample, the gas produced after $24 \mathrm{~h}$ of incubation was measured as described above and a gas sample (about $5 \mathrm{~mL}$ ) was stored in an evacuated tube (Terumo Europe N.V., Leuven, Belgium) for the analysis of $\mathrm{CH}_{4}$. Bottles were then uncapped, the $\mathrm{pH}$ was measured immediately (Crison Basic $20 \mathrm{pH}$-meter, Crisson Instruments, Barcelona, Spain), the fermentation was stopped by placing the bottles in ice water, and the following samples were taken: $2 \mathrm{~mL}$ was added to $2 \mathrm{~mL}$ of deproteinising solution $(20 \mathrm{~g}$ of metaphosphoric acid and $0.6 \mathrm{~g}$ of crotonic acid per litre) for volatile fatty acid (VFA) determination and $1 \mathrm{~mL}$ was mixed with $1 \mathrm{~mL} 0.5 \mathrm{M} \mathrm{HCl}$ for $\mathrm{NH}_{3}-\mathrm{N}$ analysis.

\subsection{In Vivo Trials}

The in vivo trials were conducted in accordance with the regulation for use of animals in experiments, adopted by the Norwegian Ministry of Agriculture and Food, and approved by the Ethics Commission on Animal Use by the Norwegian Food and Safety Authority, application number FOTS ID 8836. It complies with the EU Directive 2010/63/EU on the use of experimental animals, which was incorporated to the European Economic Area Agreement in May 2015.

\subsubsection{In Vivo Experiment 1}

Forty-eight Norwegian White sheep ewes (average BW \pm SEM of $52.6 \pm 4.1 \mathrm{~kg}$ ) were used in two replicates with 24 animals per replicate. For each replicate, the animals were distributed into six blocks according to initial weight, with the four lightest animals (block 1) randomly allocated to one of the four diets. Block 2 consisted of the next four lightest lambs and so forth until Block 6, which consisted of the four heaviest lambs. Within each block, animals were randomly allocated to one of the four diets studied. The ewes were stalled individually in an uninsulated barn at NIBIO Tjøtta in Nordland county, 
Norway $\left(65^{\circ} 49^{\prime} 22 \mathrm{~N} 12^{\circ} 25^{\prime} 37 \mathrm{E}\right)$ with free access to water. Animals were fed their daily allowances in two equal portions at 08:30 and 14:30 h. Grass silage was weighed daily and supplied ad libitum allowing a minimum of $10 \%$ leftovers. Leftover grass silage and white clover silage was measured daily, and daily intake calculated. Because the animals were skeptical regarding intake of the powdered Porphyra sp., it was mixed to a "porridge" consistency with the crushed oats, the mineral and vitamin mixture and $5 \mathrm{dl}$ of cold water. Samples of grass and clover silages were collected weekly during the trial, and frozen at $-18{ }^{\circ} \mathrm{C}$ for later analysis. Samples of the other ingredients (oats, soybean pellets and Porphyra sp.) were collected every second week and pooled for analysis.

Within each replicate, ewe's adaptation to their corresponding diets before entering the respiration chambers were allowed over a period of 20 to 27 days, due to their staggered entry to chambers. The six open circuit respiration chambers at NIBIO Tjøtta have a $25 \times 25 \mathrm{~mm}$ frame of coated steel covered with a steel mesh, that protects the exterior polycarbonate sheeting [26]. Each chamber measured $1.8 \mathrm{~m}$ wide, $1.8 \mathrm{~m}$ deep and $1.5 \mathrm{~m}$ high, making a total volume of approximately $5 \mathrm{~m}^{3}$. During the first replicate, enteric $\mathrm{CH}_{4}$ was sampled via plastic tubes into a seven port MGA 3500 multigas analyzer (ADC Gas Analysis Ltd., Hoddesdon, UK). Due to machine failure, the second replicate was sampled into a seven port Servopro Multiexact 4100 Analyzer (Servomex Group Inc., Woburn, MA, USA). Methane concentrations in ambient air and in exhaust gas leaving each chamber (in total seven ports) were measured on a rotational basis, taking one gas sample reading after 3 min per port, measuring ambient air and each chamber every $21 \mathrm{~min}$. All diets were represented in all chambers equally. The animals were kept individually in the chambers for $72 \mathrm{~h}$, during which they were fed and managed in a similar way as in the barn. Feed intake was measured daily. Water was available in buckets. Chambers were cleaned daily during morning feeding.

\subsubsection{In Vivo Experiment 2}

Twenty-four Norwegian White lambs at an age of five months and average BW \pm SEM of $32.9 \pm 0.3 \mathrm{~kg}$ were used in the experiment. The animals were blocked according to initial weight, as described in in vivo Experiment 1. The lambs were stalled individually in the uninsulated barn at NIBIO Tjøtta with free access to water and fed as described in in vivo Experiment 1. Lambs were weighed regularly throughout the trial to calculate individual growth rate and adjust feed intake to their requirements. The lambs were adapted to their diet during a 20-day period followed by a recording period of six weeks. Animals' weight gain was calculated based on start weight and weight after the six weeks recording period. Feed intake was measured four days every week during the six weeks of recording. After adaptation to the corresponding diet, two lambs within each diet were randomly picked for rumen fluid sampling, making up a total of eight samples. A short, rigid PVC tube of $12 \mathrm{~mm}$ (Tricoflex) was inserted in the esophagus of the animal before a $6 \mathrm{~mm}$ flexible PVC tube (Tricoflex) with about 12 holes of $3 \mathrm{~mm}$ diameter was inserted into the rumen to a depth of approximately $120 \mathrm{~cm}$ via the plastic tube. Rumen samples (ca. $50 \mathrm{~mL}$ ) were obtained using an electric vacuum pump (Edwards RV5, serial no 119464845, West Sussex, UK). The rumen samples were examined visually to ensure they were not contaminated with saliva. The samples were strained through a layer of leno bandage (Mesoft, Mölnlycke health care, Göteborg, Sweden) and pH values were measured immediately using a pH-meter (VWR International pHenomenal, PC $5000 \mathrm{H}$, Serial no 11232089, Leuven, Belgium) following the methodology described by Ramos-Morales et al. [27]. Four milliliters of rumen filtrate were acidified with $4 \mathrm{~mL}$ of $0.5 \mathrm{M} \mathrm{HCL}$ for ammonia determinations and another $4 \mathrm{~mL}$ sample was deproteinized with $4 \mathrm{~mL}$ of a crotonic solution $(250 \mathrm{~mL}$ HCL $0.5 \mathrm{M}, 0.5 \mathrm{~g}$ crotonic acid and $5 \mathrm{~g}$ of metaphosphoric acid) for determination of acetate concentration. All samples were freeze dried and stored at $-80{ }^{\circ} \mathrm{C}$ until analysis. 


\subsection{Chemical Analyses}

\subsubsection{In Vitro Trial}

Ground (1 mm) samples of diets and Porphyra sp. were analyzed for DM, organic matter (OM), and ether extract (EE) according to the AOAC [28]. After N determination using a Leco TruSpec CN ${ }^{\circledR}$ (Leco Empowering Results, St. Joseph, MI, USA), crude protein (CP) was calculated by multiplying by 6.25. The neutral detergent fiber (NDF) and acid detergent fiber (ADF) were analyzed according to Van Soest et al. [29] using an ANKOM Model 220 Fiber Analyzer (Macedon, NY, USA) with $\alpha$-amylase for NDF analysis in concentrate samples, and both NDF and ADF contents referred to ash-free weight. The acid detergent lignin (ADL) was determined by solubilization of cellulose with $72 \%$ sulphuric acid. The energy content was determined using an oxygen bomb calorimeter (PARR 1356, Biometer ${ }^{\circledR}$ ). Free, protein-bound and fiber-bound condensed tannins in diet samples were sequentially extracted following the procedure described by Perez-Maldonado and Norton [30] using condensed tannins from quebracho powder (Roy Wilson Dickson Ltd., Mold, UK) as a standard.

The $\mathrm{CH}_{4}$ concentration was determined by gas chromatography (GC) using a HP Hewlett 5890, Packard Series II gas chromatograph (Waldbronn, Germany) equipped with a flame ionization detector (FID) and with an HP-INNOWAX crosslinked polyethylene glycol column $(25 \mathrm{~m} \times 0.2 \mathrm{~mm} \times 0.2 \mu \mathrm{m})$. The carrier gas was He, and peaks were identified by comparison with a standard of known composition. A sample of $0.5 \mathrm{~mL}$ of gas was injected using a $1 \mathrm{~mL}$ Sample-Lock ${ }^{\circledR}$ syringe (Hamilton, Nevada, USA). Total and individual VFA were analyzed by gas chromatography following the methodology described by Isac et al. [31]. The concentration of $\mathrm{NH}_{3}-\mathrm{N}$ was determined following the colorimetric method of Weatherburn et al. [32] using a spectrophotometer (Thermo Scientific, Genesys $10 \mu \mathrm{V}$ Scanning, Madison, WI 53, 711 USA).

\subsubsection{In Vivo Trials}

Samples of grass and clover silages were analyzed using NIRs by Eurofins Norway performed at Eurofins Agro Testing Wageningen (Binnenhaven 5, NL-6709 PD, Wageningen ISO/IEC 17025:2005 RvA L122) for DM, ash, CP and NDF content. Soybean meal pellets and crushed oats were analyzed by Eurofins Norway performed at Eurofins Food \& Feed Testing Sweden (Lidköping) (Sjöhagsgatan 3, port 2, 531 40, Lidköping ISO/IEC 17025:2005 SWEDAC 1977) for DM, N by the Kjeldahl method, ash (2009/152/EU) and NDF (ISO/CD 16472). Ammonia and acetate concentrations in rumen samples were analyzed by following the respective methodologies described for in vitro trial.

\subsection{Calculations and Statistical Analysis}

The gas produced in batch cultures was adjusted to the exponential model: $y=A\left(1-\mathrm{e}^{(-\mathrm{c}(\mathrm{t}-\mathrm{lag})}\right)$, where $y$ represents the cumulative gas production $(\mathrm{mL}), \mathrm{t}$ the incubation time $(\mathrm{h}), \mathrm{A}$ the asymptote (total gas; $\mathrm{mL}$ ) and $\mathrm{c}$ the organic matter degradation rate $\left(\mathrm{h}^{-1}\right)$, and lag $(\mathrm{h})$ is the initial delay in the onset of gas production. The parameters A, c and lag were estimated by an iterative least square procedure using the NLIN procedure of SAS (version 9.4; SAS Inst. Inc., Cary, NC, USA). The average gas production rate (AGPR; $\mathrm{mL}$ gas/h) is defined as the average gas production rate between the start of the incubation and T1/2 and was calculated as AGPR $=\mathrm{A} \mathrm{c} /[2(\ln 2+\mathrm{c}$ lag) $]$. Finally, the effective DM degradability (EDMD) was estimated assuming a rumen particulate outflow (Kp) of 0.03 per $h$ according to the equation: $\operatorname{EDMD}=[(\operatorname{TDMD} c) /(c+K p)] \mathrm{e}^{(-\mathrm{clag})}$.

The amount of VFA in the batch culture bottles after $24 \mathrm{~h}$ of incubation both for control and experimental diets was corrected for VFA in the rumen liquid used as inoculum. The amount of $\mathrm{CH}_{4}$ produced was calculated by multiplying the gas produced with its concentration in $\mathrm{CH}_{4}$.

The SPSS for Windows, version 19.0 (2010; SPSS Inc., Chicago, IL, USA) was used for in vitro trial data entry and statistical analysis. Data were analyzed using the ANOVA procedure considering diet as a fixed effect and incubation run as a random effect. When a significant $(p<0.05)$ effect of diet was 
found, post hoc comparison of means was made using the Tukey test. Differences were considered significant at $p<0.05$ and trend at $0.05<p \leq 0.10$.

The Minitab for Windows version 17.3.0 (2016 Minitab Inc, Coventry, United Kingdom) was used for the in vivo trial data and statistical analysis. To determine in vivo $\mathrm{CH}_{4}$ production and lambs' daily weight gain between different diets, data were analyzed using the ANOVA procedure considering block and diet as fixed effects and animals as random effects. When a significant effect of block or diet was found, post hoc comparison of means was made using the Tukey test. Differences were considered significant at $p<0.05$ and trend at $0.05<p \leq 0.10$.

\section{Results}

\subsection{In Vitro Trial}

Diet only affected $(p=0.002) \mathrm{pH}$ values (Table 3), being higher for the POR diet compared with the other studied diets. Diet tended to affect total VFA produced $(p=0.092)$ and isovalerate proportion $(p=0.082)$ but no effect of diet on other VFA molar proportions and the acetate to propionate ratio was observed.

Table 3. Average values of $\mathrm{pH}$, total volatile fatty acids (VFA) produced and molar proportions of individual VFA and acetate:propionate ratios after $24 \mathrm{~h}$ of incubation of the experimental diets in batch cultures inoculated with ruminal microorganisms from sheep.

\begin{tabular}{|c|c|c|c|c|c|c|c|c|c|}
\hline \multirow{2}{*}{ Diet $^{1}$} & \multirow{2}{*}{$\mathrm{pH}$} & \multirow{2}{*}{$\begin{array}{c}\text { VFA } \\
\text { (mmol) }\end{array}$} & \multicolumn{6}{|c|}{ Molar Proportions (mol/100 mol) } & \multirow{2}{*}{$\begin{array}{l}\text { Acetate/Propionate } \\
\text { (mol/mol) }\end{array}$} \\
\hline & & & Acetate & Propionate & Butyrate & Isobutyrate & Isovalerate & Valerate & \\
\hline $\mathrm{CON}$ & $6.76^{\mathrm{a}}$ & 2.29 & 62.5 & 24.1 & 10.2 & 0.263 & 1.51 & 1.43 & 2.67 \\
\hline SOY & $6.75^{\mathrm{a}}$ & 2.43 & 62.2 & 24.1 & 10.1 & 0.288 & 1.73 & 1.51 & 2.66 \\
\hline POR & $6.82^{b}$ & 2.35 & 62.1 & 24.4 & 10.2 & 0.256 & 1.62 & 1.45 & 2.62 \\
\hline SEM $^{2}$ & 0.012 & 0.023 & 0.944 & 0.952 & 0.365 & 0.023 & 0.083 & 0.140 & 0.150 \\
\hline
\end{tabular}

${ }^{1}$ CON: control diet; CLO: diet including clover silage; SOY: diet including soybean meal; POR: diet including Porphyra sp.; ${ }^{2}$ SEM: standard error of the mean; ${ }^{\mathrm{a}, \mathrm{b}}$ Means that do not share a letter are significantly different.

No effect of diet was observed (Table 4) for ammonia concentration, $\mathrm{CH}_{4}$ produced (mL/g incubated $\mathrm{DM})$ and the $\mathrm{CH}_{4}$ to VFA ratio.

Table 4. Average values of $\mathrm{NH}_{3}-\mathrm{N}$ concentrations $(\mathrm{mg} / 100 \mathrm{~mL})$, production of methane (mL/g DM), and methane/total volatile fatty acids (methane/VFA mol/mol) ratios after $24 \mathrm{~h}$ of incubation of the experimental diets in batch cultures inoculated with ruminal microorganisms from sheep.

\begin{tabular}{cccc}
\hline Diet $^{\mathbf{1}}$ & $\mathbf{N H}_{\mathbf{3}}$ & Methane & Methane/VFA \\
\hline CON & 10.5 & 69.6 & 12.3 \\
CLO & 9.95 & 63.8 & 10.6 \\
SOY & 11.8 & 72.7 & 12.2 \\
POR & 11.0 & 72.5 & 12.5 \\
SEM $^{2}$ & 0.760 & 4.26 & 0.854 \\
$p$ value & 0.345 & 0.253 & 0.955 \\
\hline
\end{tabular}

${ }^{1} \mathrm{CON}$ : control diet; $\mathrm{CLO}$ : diet including clover silage; SOY: diet including soybean meal; POR: diet including Porphyra sp.; ${ }^{2}$ SEM: standard error of the mean.

The same pattern (no effect of diet) was observed for gas kinetic characteristics A and AGPR (Table 5), EDMD and TDMD, while diet tended to affect the fraction rate of gas production, $\mathrm{c}(p=0.090)$. 
Table 5. Gas production kinetics (A, c and AGPR), effective dry matter degradability (EDMD) and true dry matter digestibility (TDMD) after $72 \mathrm{~h}$ of incubation of the experimental diets in batch cultures inoculated with ruminal microorganisms from sheep.

\begin{tabular}{|c|c|c|c|c|c|}
\hline \multirow{2}{*}{$\operatorname{Diet}^{1}$} & \multicolumn{5}{|c|}{ Parameters of Gas Production Kinetics ${ }^{2}$} \\
\hline & $A(m L)$ & $c\left(h^{-1}\right)$ & AGPR (mL/h) & $\operatorname{EDMD}(\mathrm{g} / \mathrm{kg})^{3}$ & TDMD (g/kg) ${ }^{4}$ \\
\hline $\mathrm{CON}$ & 107 & 0.058 & 4.50 & 57.8 & 87.7 \\
\hline $\mathrm{CLO}$ & 107 & 0.097 & 4.80 & 58.9 & 87.3 \\
\hline SOY & 110 & 0.058 & 4.57 & 58.1 & 88.3 \\
\hline POR & 107 & 0.061 & 4.67 & 58.6 & 87.6 \\
\hline SEM $^{5}$ & 0.617 & 0.002 & 0.015 & 0.440 & 0.183 \\
\hline$p$ value & 0.230 & 0.090 & 0.102 & 0.814 & 0.319 \\
\hline
\end{tabular}

1 CON: control diet; CLO: diet including clover silage; SOY: diet including soybean meal; POR: diet including Porphyra sp.; ${ }^{2}$ A: asymptotic gas production; c: fractional rate of gas production; AGPR: average gas production rate. The values of lag were 0 for all samples. ${ }^{3}$ EDMD: Effective dry matter degradability for a rumen particulate outflow of $0.03 / \mathrm{h} ;{ }^{4}$ Calculated as described by Van Soest et al. [24]; ${ }^{5}$ SEM: standard error of the mean.

\subsection{In Vivo Trials}

\subsubsection{In Vivo Experiment 1}

The DM intake during the stay of sheep in respiration chambers (Table 6) was lower $(p=0.005)$ for animals receiving CON and SOY diets compared with CLO and POR diets. However, $\mathrm{CH}_{4}$ produced (L/kg DM intake) was not different depending on diet. There were no changes in animals' live weight during the trial and thus no differences in live weight between sheep fed the four diets (results not shown).

Table 6. Average daily DM intake (g/day) and enteric methane production $\left(\mathrm{L} \mathrm{CH}_{4} / \mathrm{kg} \mathrm{DM}\right)$ in sheep fed the experimental diets in in vivo Experiment 1.

\begin{tabular}{ccc}
\hline Diet $^{\mathbf{1}}$ & DM & $\mathbf{C H}_{\mathbf{4}}$ \\
\hline CON & $1343^{\mathrm{a}}$ & 22.8 \\
CLO & $1544^{\mathrm{b}}$ & 29.1 \\
SOY & $1466^{\mathrm{ab}}$ & 24.6 \\
POR & $1507^{\mathrm{b}}$ & 24.6 \\
SEM $^{2}$ & 21.3 & 1.26 \\
$p$ value & 0.005 & 0.327
\end{tabular}

${ }^{1}$ CON: control diet; CLO: diet including clover silage; SOY: diet including soybean meal; POR: diet including Porphyra sp.; ${ }^{2}$ SEM: standard error of the mean; ${ }^{a, b}$ Means that do not share a letter are significantly different.

\subsubsection{In Vivo Experiment 2}

Lambs fed the CLO diet had higher $(p<0.001)$ DM, CP, NDF, digestible organic matter (DOM) and energy (FU) intake (Table 7) compared to lambs fed the CON diet. The lambs fed the SOY and POR diets had intermediate intakes, different from the animals receiving CON and CLO diets, except for FU, which was also higher for the POR diet. However, the growth rate was higher $(p<0.001)$ for SOY and POR diets compared to CON and CLO diets. The variation of growth rate was from $254 \mathrm{~g}$ per day for the SOY lambs to $161 \mathrm{~g}$ per day for the CLO lambs. 
Table 7. Average DM, CP, NDF, DOM (g/d) and feed unit (FU) intake and growth rate (g/d) of lambs fed the experimental diets in in vivo Experiment 2.

\begin{tabular}{ccccccc}
\hline Diet $^{1}$ & DM & CP & NDF & DOM & Feed Units $^{3}$ & Growth Rate \\
\hline CON & $1395^{\mathrm{a}}$ & $115^{\mathrm{a}}$ & $712^{\mathrm{a}}$ & $1046^{\mathrm{a}}$ & $1.17^{\mathrm{a}}$ & $163.3^{\mathrm{a}}$ \\
CLO & $1967^{\mathrm{c}}$ & $246^{\mathrm{d}}$ & $1015^{\mathrm{c}}$ & $1222^{\mathrm{b}}$ & $1.38^{\mathrm{bc}}$ & $160.5^{\mathrm{a}}$ \\
SOY & $1625^{\mathrm{b}}$ & $223^{\mathrm{c}}$ & $798^{\mathrm{b}}$ & $1251^{\mathrm{b}}$ & $1.42^{\mathrm{c}}$ & $253.8^{\mathrm{b}}$ \\
POR $^{\mathrm{b}}$ & $1600^{\mathrm{b}}$ & $202^{\mathrm{b}}$ & $803^{\mathrm{b}}$ & $1227^{\mathrm{b}}$ & $1.34^{\mathrm{b}}$ & $249.0^{\mathrm{b}}$ \\
SEM $^{2}$ & 11.6 & 1.69 & 6.13 & 127.8 & 0.14 & 12.3 \\
$p$ value & $<0.001$ & $<0.001$ & $<0.001$ & $<0.001$ & $<0.001$ & $<0.001$
\end{tabular}

${ }^{1} \mathrm{CON}$ : control diet; CLO: diet including clover silage; SOY: diet including soybean meal; POR: diet including Porphyra sp.; ${ }^{2}$ SEM: standard error of the mean; ${ }^{3}$ FU Scandinavian Feed Unit-1 FU = 7.89 MJ net energy; ${ }^{a, b, c}$ Means that do not share a letter are significantly different.

The average $\mathrm{pH}$ in sheep rumen was not affected by diet (Table 8). Concentration of ammonia was lower $(p<0.001)$ in the rumen of animals fed the CON diet compared to the animals fed the CLO, SOY and POR diets. The concentration of acetate in the rumen was affected by diet $(p=0.040)$, being higher for CON and POR diets compared with CLO and SOY diets.

Table 8. Average values of $\mathrm{pH}$, concentration of ammonia $(\mathrm{mg} / 100 \mathrm{~mL})$ and of acetate $(\mathrm{mmol} / \mathrm{L})$ in the rumen of sheep fed the experimental diets in in vivo Experiment 2.

\begin{tabular}{cccc}
\hline Diet $^{1}$ & $\mathbf{p H}$ & $\mathbf{N H}_{3}$ & Acetate \\
\hline CON & 7.21 & $10.2^{\mathrm{a}}$ & $44.5^{\mathrm{b}}$ \\
CLO & 7.60 & $23.0^{\mathrm{b}}$ & $38.0^{\mathrm{a}}$ \\
SOY & 7.50 & $26.1^{\mathrm{b}}$ & $38.4^{\mathrm{a}}$ \\
POR & 7.09 & $21.4^{\mathrm{b}}$ & $47.5^{\mathrm{b}}$ \\
SEM $^{2}$ & 0.111 & 1.06 & 5.12 \\
$p$ value & 0.357 & 0.001 & 0.040 \\
\hline
\end{tabular}

${ }^{1}$ CON: control diet; CLO: diet including clover silage; SOY: diet including soybean meal; POR: diet including Porphyra sp.; ${ }^{2}$ SEM: standard error of the mean; ${ }^{\mathrm{a}, \mathrm{b}}$ Means that do not share a letter are significantly different.

\section{Discussion}

In the present work, we tested the hypothesis that Porphyra sp. can substitute soybean meal or clover silage as a protein source in sheep diets without affecting ruminal fermentation, growth rate and enteric $\mathrm{CH}_{4}$ production. Porphyra sp. was chosen as the seaweed source based on in vitro and in situ results by Tayyab et al. [7], Molina-Alcaide et al. [8] and Gaillard et al. [9]. Most commonly, Porphyra is known as nori and used as wrapping for sushi and eaten in soups in Japan. Porphyra is not cultivated or harvested on industrial scale for feed production in Europe and the use of Porphyra as a protein source for animal feed is therefore a challenge. However, the study of seaweed as a potential protein source in animal feed has global relevance, since the cultivation potential of seaweed is not in competition with current land use. Recently, research has focused on both brown and red seaweed species. While brown seaweeds, such as Saccharina latissima, contain phlorotannins, which prevent protein degradation, red species can be a source of bypass protein [7] and amino acids which can be utilized by ruminants [9]. Therefore, red seaweed species show promise as an alternative to more commonly used products such as soybean meal.

\subsection{In Vitro}

There were no differences among diets in total VFA production or in VFA profile. In contrast to De la Moneda et al. [19], the POR diet did not differ from the CON diet in VFA profile or the acetate/propionate ratio. Compared with the Porphyra diet used by De la Moneda et al. [19], the total VFA production in the POR diet was lower. However, the molar proportions of the individual VFA were similar to De la Moneda et al. [19], although the acetate/propionate ratio was slightly lower for 
POR $(2.62 \mathrm{~mol} / \mathrm{mol})$ compared to [19] $(3.2 \mathrm{~mol} / \mathrm{mol})$. The lack of differences in $\mathrm{NH}_{3}$ concentration between diets also indicates similar protein degradability. $\mathrm{CH}_{4}$ production did not differ between the diets and neither did the $\mathrm{CH}_{4} / \mathrm{VFA}$ ratio. The $\mathrm{CH}_{4} / \mathrm{VFA}$ ratio can be used as an indicator of the efficiency of ruminal fermentation, because $\mathrm{CH}_{4}$ is an energy loss for the host animal and VFA is used as an energy source and as substrates for the synthesis of other compounds [33].

In the present study, no differences in total gas production (A), c or AGPR were found. This is comparable to results by De la Moneda et al. [19], who found that diets including Porphyra sp. did not reduce the extent of fermentation compared to a control diet. This confirms that the in vitro degradation of the diets was similar for all four diets and that inclusion of white clover silage or Porphyra sp. can substitute soybean meal without compromising rumen fermentation.

\subsection{In Vivo}

The three protein sources studied were white clover silage, soybean meal and powdered Porphyra $\mathrm{sp}$. The protein content differed between the sources, with soybean meal having higher proportions than Porphyra sp. and clover silage. Diets with protein enrichment (CLO, SOY and POR) were planned to be isoenergetic and isoproteinic, but chemical analysis showed that the SOY diet had a higher crude protein content compared to CLO and POR diets. As dietary protein concentration increases, organic matter, dry matter and hemicellulose digestibility increase due to enhanced microbial enzyme and VFA production [34]. Tayyab et al. [7] demonstrated, using in situ methods, that Porphyra sp. can supply the rumen with high amounts of degradable protein and supply a high amount of rumen escapable protein, digestible in the small intestine. The CP concentration in Porphyra sp. was compared with that of oil-seed by-products, such as sunflower meal and rapeseed meal. The total DM intake in the present trial showed a similar pattern in the two experiments. The lowest DM intake was observed for animals fed the CON diets, while the highest intake was observed for animals fed the CLO diet resulting in the highest $\mathrm{CP}$ intake. Both these diets were based on silages with crushed oats and vitamin-mineral mixture.

In an Australian experiment, enteric $\mathrm{CH}_{4}$ emissions were reduced by up to $67 \%$ when the red seaweed species Asparagopsis armata was included at $1.0 \%$ of the total diet offed to dairy cows [12]. Li et al. [21] investigated A. taxiformis in diets to sheep at inclusions of $0.5 \%, 1 \%, 2 \%$ and $3 \%$ and found up to an $80 \%$ reduction in enteric $\mathrm{CH}_{4}$ compared to a control diet. They suggest that the inhibition of methanogenesis was due to the presence of accumulated halogenated metabolites in the Asparagopsis biomass [21]. It is suggested that bromoform, one of four haloforms, the others being fluoroform, chloroform and iodoform, inhibits the methanogens in the final enzymatic step of methanogenesis in the rumen. Bromoform is also characterized as a volatile halogenated hydrocarbon and exhibits a wide range of pharmacological activities [35]. Brominated fatty acids are primarily synthesized by Asparagopsis [36]. Condensed tannins are suggested to reduce $\mathrm{CH}_{4}$ production, as demonstrated in a Canadian experiment with beef cattle [37]. In Table 2, the content of condensed tannins is reported, and it shows small differences between the diets.

In our experiment, the inclusion of seaweed constituted almost $10 \%$ of the total DM to ensure that the diets were both isoenergetic and isoproteinic. The high inclusion of Porphyra sp. was challenging due to palatability, requiring the preparation of a porridge to enable the animals to eat their daily ration. We did not find that Porphyra sp. influenced enteric $\mathrm{CH}_{4}$. De la Moneda et al. [19] concluded that none of the seven different seaweed species, including Porphyra sp., tested in vitro for enteric $\mathrm{CH}_{4}$ emission, had a noticeable anti-methanogenic effect. We measured values of enteric $\mathrm{CH}_{4}$ from sheep fed the diets in respiration chambers between 22.8-29.1 L/kg DM intake, which is in accordance with observations made in goats [16,38], sheep [39] and cattle [40]. The in vivo results supported the results of the in vitro study, which also showed no significant differences in $\mathrm{CH}_{4}$ emission between diets.

The protein value of Porphyra sp. was shown by Tayyab et al. [7] and Gaillard et al. [9] to be similar to, e.g., the protein value of rapeseed meal. The soybean pellets in this experiment had a higher protein concentration in DM than that of Porphyra sp. (54.5 and $37.1 \mathrm{~g} / \mathrm{kg}$ fresh matter, respectively, 
Table 1) with a slight difference also in protein intake (223 and $202 \mathrm{~g} / \mathrm{d}$ for SOY and POR, respectively) (Table 7). However, lambs fed these diets showed a similar growth rate (254 and $249 \mathrm{~g} / \mathrm{d}$, respectively). The high CP intake for animals fed the CLO diet was not reflected by a corresponding increase in daily growth rate $(161 \mathrm{~g} / \mathrm{d})$ but was instead similar to the growth rate for animals fed the CON diet $(163 \mathrm{~g} / \mathrm{d})$. The higher content of NDF in the CLO diet could explain the lack of response in growth rate. The digestibility of NDF varies among different forages and affects animal performance. Lactating dairy cows fed silages with similar NDF and CP contents but different NDF digestibility performed significantly differently in DM intake and milk yield [41]. It is suggested that inclusion of white clover in a diet increases voluntary feed intake due to a more rapid particle breakdown, faster rumen fermentation and lower mean rumen retention time [15]. For digestible organic matter intake and intake of energy (Feed Units), lambs fed the CON diet had lower intake than for the CLO, SOY and POR diets. The lower growth rate of lambs in the CLO diet does not seem to be explained by protein or energy intake. The higher growth rate of lambs in the SOY and POR diets is possibly due to a high degree of bypass protein entering the intestine from the protein sources soybean meal and Porphyra sp. The latter confirms the in vitro and in situ findings by Tayyab et al. [7] and Gaillard et al. [9].

White clover silage was not included in the studies of Tayyab et al. [7] and Gaillard et al. [9], and it is thus not possible to compare the present in vivo data with similar in vitro data. However, Damborg et al. [42] found similar in situ total tract protein degradability for white clover $(911 \mathrm{~g} / \mathrm{kg})$ as Tayyab et al. [7] found for Porphyra sp. (906 g/kg). The white clover varieties in the Danish experiment were Klondyke and Silvester, while in the present study the variety Litago was used due to its adaption to arctic conditions. To our knowledge, the protein quality of Litago has not been studied, so it is not possible to confirm if it is of similar quality to the Danish varieties.

The nutritive value of proteins supplied in the diet depends on the proportions of amino acids that are digested and made available to the animal. The supply of essential amino acids relative to total energy supply influences the absolute and relative rate of protein and fat accretion in lambs. It is well documented that methionine and cysteine are the primary limiting amino acids for wool production and both wool production and live weight gain can be improved by supplementing sheep with methionine [43]. Gaillard et al. [9] showed that most of the seaweeds investigated (Porphyra incl.) were deficient in essential amino acids compared to soybean, except for sulphur-amino acids. Most amino acids are degraded in the rumen and, to characterize a feedstuff, amino acids that escape to the small intestine are important [44]. Gaillard et al. [9] concluded that Porphyra can be considered as relevant source of protein for ruminants based on the amount of amino acids and their degradability but should be harvested during spring when higher quantities of amino acids are present.

The diet effects of ammonia and acetate concentrations in the rumen were different for the in vivo and in vitro experiments. While there was no response to diet in vitro, the CON diet resulted in lower ammonia concentration compared to the three protein-supplemented diets in vivo. The ammonia concentration in the CON diet was similar to all the observed in vitro concentrations (around $10 \mathrm{mg} / 100 \mathrm{~mL}$ ). This could be explained by the lower protein content in the CON diet compared to the other three diets, indicating that in vitro methods do not necessarily mirror in vivo ammonia. A review by Eschenlauer [45] concludes that different methodologies and substrate concentrations explain different rates of ammonia production in the rumen of sheep.

\section{Conclusions}

Both in vivo and in vitro results indicate that Porphyra sp. does not act as a tool to reduce enteric methane emissions. We show that Porphyra sp. has a protein value similar to high quality protein sources, such as soybean meal. This in vivo study confirms that Porphyra sp. is a comparably effective protein source when compared with soybean meal. On the other hand, Porphyra sp. is not effective in reducing enteric methane. The use of seaweed species as a protein source in animal production faces some practical and economic challenges before it can substitute soybean meal and be implemented in the daily diet of ruminants. 
Author Contributions: Conceptualization and methodology, V.L., M.R.W. and E.M.-A.; Investigation, V.L., E.M.-A., G.M.J., J.E.F.-Y., L.A.; Formal analysis, V.L., E.M.-A., J.E.F.-Y., L.A.; Project administration, V.L.; Funding, V.L., M.R.W., E.M.-A.; Writing original draft and editing, V.L., M.R.W., E.M.-A., G.M.J. All authors have read and agreed to the published version of the manuscript.

Funding: Funding for this study was provided by the Research Council of Norway (Project Legumes and seaweed as alternative protein sources for sheep-AltPro. No 233682/E50, Norway).

Acknowledgments: The authors would like to thank Arne Johan Lukkassen and Roberts Sturitis for technical assistance.

Conflicts of Interest: The authors declare no conflict of interest.

\section{References}

1. FAO. Available online: http://www.fao.org/fileadmin/templates/wsfs/docs/Issues_papers/Issues_papers_SP/ La_agricultura_mundial.pdf (accessed on 29 October 2019).

2. Magrini, M.-B.; Anton, M.; Cholez, C.; Corre-Hellou, G.; Duc, G.; Jeuffroy, M.-H.; Meynard, J.-M.; Pelzer, E.; Voisin, A.-S.; Walrand, S. Why are grain-legumes rarely present in cropping systems despite their environmental and nutritional benefits? Analysing lock-in in the French agrifood system. Ecol. Econ. 2016, 126, 152-162. [CrossRef]

3. Lundeberg, H. Soya i norsk fôr-Forbruk og arealbeslag. Framtiden i våre hender 2018, 7, 18. Available online: https://www.framtiden.no/aktuelle-rapporter/852-soya-i-norsk-for-forbruk-og-arealbeslag/file.html (accessed on 30 December 2019). (In Norwegian)

4. Forskrift om forbud mot omsetning i Norge av bestemte genmodifiserte produkter. Klima- og Miljødepertementet. 2000. Available online: https://lovdata.no/dokument/SF/forskrift/2000-12-15-1268?q= forbud\%20GMO (accessed on 30 December 2019). (In Norwegian)

5. Bay-Larsen, I.; Risvoll, C.; Vestrum, I.; Bjørkhaug, H. Local protein sources in animal feed-Perceptions among arctic sheep farmers. J. Rural Studies 2018, 59, 98-110. [CrossRef]

6. Burtin, P. Nutritional value of seaweeds. Electron. J. Environ. Agri. Food Chem. 2003, 2, 498-503.

7. Tayyab, U.; Novoa-Garrido, M.; Roleda, M.Y.; Lind, V.; Weisbjerg, M.R. Ruminal and intestinal protein degradability of various seaweed species measured in situ in dairy cows. Anim. Feed Sci. Technol. 2016, 213, 44-54. [CrossRef]

8. Molina-Alcaide, E.; Carro, M.D.; Roleda, M.Y.; Weisbjerg, M.R.; Lind, V.; Novoa Garrido, M. In vitro ruminal fermentation and methane production of different seaweed species. Anim. Feed Sci. Technol. 2017, 228, 1-12. [CrossRef]

9. Gaillard, C.; Bhatti, H.S.; Novoa-Garrido, M.; Lind, V.; Roleda, M.Y.; Weisbjerg, M.R. Amino acid profiles of nine seaweed species and their in situ degradability in dairy cows. Anim. Feed Sci. Technol. 2018, 241, 210-222. [CrossRef]

10. Fleurence, J. Seaweed proteins: Biochemical, nutritional aspects and potential uses. Trends Food Sci. Technol. 1999, 10, 25-28. [CrossRef]

11. Shuuluka, D.; Bolton, J.J.; Anderson, R.J. Protein content, amino acid composition and nitrogen-to-protein conversion factors of Ulva rigida and Ulva capensis from natural populations and Ulva lactuca from an aquaculture system, in South Africa. J. Appl. Phycol. 2013, 2, 677-685. [CrossRef]

12. Roque, M.B.; Salwen, J.K.; Kinley, R.; Kebreab, E. Inclusion of Asp.aragopsis armata in lactating dairy cows' diet reduces enteric methane emission by over 50 percent. J. Cleaner Prod. 2019, 234, 132-138. [CrossRef]

13. Özkan-Gülzari, S.; Lind, V.; Aasen, I.M.; Steinshamn, H. Effect of supplementing sheep diets with macroalgae species on in vivo nutrient digestibility, rumen fermentation and blood amino acid profile. Animal 2019, 13, 2792-2801. [CrossRef]

14. Søegaard, K. Nutritive Value of White Clover. 1993. Available online: http://www.fao.org/3/v2350e/v2350e03. htm (accessed on 30 December 2019).

15. Johansen, M.; Søegaard, K.; Lund, P.; Weisbjerg, M.R. Digestibility and clover proportion determine milk production when silages of different grass and clover species are fed to dairy cows. J. Dairy Sci. 2017, 100, 8861-8880. [CrossRef] [PubMed] 
16. Romero-Huelva, M.; Ramírez-Fenosa, M.A.; Planelles-González, R.; García-Casado, P.; Molina-Alcaide, E. Can by-products replace conventional ingredients in concentrate of dairy goat diet? J. Dairy Sci. 2017, 100, 4500-4512. [CrossRef] [PubMed]

17. Fernandez, C.; Marti, J.V.; Perez-Baena, I.; Palomares, J.L.; Ibanez, C.; Segarra, J.V. Effect of lemon leaves on energy and C-N balances, methane emission, and milk performance in Murciano-Granadina dairy goats. J. Anim. Sci. 2018, 96, 1508-1518. [CrossRef]

18. Adegbeye, M.J.; Elghandour, M.M.Y.; Monroy, J.C.; Abegunde, T.O.; Salem, A.Z.M.; Barbabosa-Pliego, A.; Faniyi, T.O. Potential influence of Yucca extract as feed additive on greenhouse gases emission for a cleaner livestock and aquaculture farming-A review. J. Clean. Prod. 2019, 239. [CrossRef]

19. De la Moneda, A.; Carro, M.D.; Weisbjerg, M.R.; Roleda, M.Y.; Lind, V.; Novoa-Garrido, M.; Molina-Alcaide, E. Variability and potential of seaweeds as ingredients of ruminant diets: An in vitro study. Animals 2019, 9, 851. [CrossRef]

20. Makkar, H.P.S.; Tran, G.; Heuzé, V.; Giger-Reverdin, S.; Lessire, M.; Lebas, F.; Ankers, P. Seaweeds for livestock diets: A review. Anim. Feed Sci. Technol. 2016, 212, 1-17. [CrossRef]

21. Li, X.; Norman, H.C.; Kinley, R.D.; Laurence, M.; Wilmot, M.; Bender, H.; de Nys, R.; Tomkins, N. Asp.aragopsis taxiformis decreases enteric methane production from sheep. Anim. Prod. Sci. 2018, 58, 681-688. [CrossRef]

22. Eurofins. Næringsinnhold i grovfôr til drøvtyggere. Available online: https://cdnmedia.eurofins. com/european-east/media/2848751/naeringsinnhold-i-grovf\%C3\%B4r-til-droevtyggere.pdf (accessed on 30 December 2019). (In Norwegian)

23. Aguilera, J.F.; Molina-Alcaide, E.; Prieto, C.; Boza, J. Determination of the energy requirements for maintenance in sheep of Segureña breed. Arch. Zootec. 1986, 35, 89-96.

24. Theodorou, M.K.; Williams, B.A.; Dhanoa, M.S.; McAllan, A.B.; France, J. A simple gas production method using a pressure transducer to determine the fermentation kinetics of ruminant feeds. Anim. Feed. Sci. Technol. 1994, 48, 185-197. [CrossRef]

25. Goering, M.K.; Van Soest, P.J. Forage Fiber Analysis (Apparatus, Reagents, Procedures and Some Applications). In Agrictultural Handbook; Agriculture Handbook No. 379; Agricultural Research Services: Washington, DC, USA, 1970.

26. Pinares, C.; Waghorn, G. Technical Manual on Respiration Chambers Designs; Publisher Ministry of Agriculture and Forestry, New Zealand. 2014. Available online: https://www.globalresearchalliance.org/wpcontent/uploads/2012/03/GRA-MAN-Facility-BestPract-2012-ch13.pdf (accessed on 30 December 2019).

27. Ramos-Morales, E.; Arco-Pérez, A.; Martín-García, A.I.; Yáñez-Ruiz, D.R.; Frutos, P.; Hervás, G. Use of stomach tubing as an alternative to rumen cannulation to study ruminal fermentation and microbiota in sheep and goats. Anim. Feed Sci. Technol. 2014, 198, 57-66. [CrossRef]

28. Association of Official Analytical Chemists (AOAC). Official Methods of Analysis, 18th ed.; AOAC International: Gaithersburg, MD, USA, 2005.

29. Van Soest, P.J.; Win, R.; Moor, L. Estimation of the true digestibility of forages by the in vitro digestion of cell walls. In Proceedings of the 10th International Grassland Congress, Helsinki, Finland, 7-16 July 1966; pp. 438-441.

30. Perez-Maldonado, R.A.; Norton, B.W. Digestion of 14C-labelled condensed tannins from Desmodium intortum in sheep and goats. Br. J. Nutr. 1996, 76, 501-513. [CrossRef] [PubMed]

31. Isac, M.D.; García, M.A.; Aguilera, J.F.; Molina-Alcaide, E. A comparative study of nutrient digestibility, kinetics of digestion and passage and rumen fermentation pattern in goats and sheep offered medium quality forages at the maintenance level of feeding. Arch. Anim. Nutr. 1994, 46, 37-50. [CrossRef] [PubMed]

32. Weatherburn, M.W. Phenol-hypochlorite reaction for determination of ammonia. Anal. Chem. 1967, 39, 971-974. [CrossRef]

33. Vanegas, J.L.; González, J.; Carro, M.D. Influence of protein fermentation and carbohydrate source on in vitro methane production. J. Anim. Physiol. Anim. Nutr. 2017, e288-e296. [CrossRef]

34. Griswold, K.E.; Apgar, G.A.; Bouton, J.; Firkins, J.L. Effects of urea infusion and ruminal degradable protein concentration on microbial growth, digestibility and fermentation in continuous culture. J. Anim. Sci. 2003, 81, 329-336. [CrossRef]

35. Holdt, S.L.; Kraan, S. Bioactive compounds in seaweed: Functional food applications and legislation. J. Appl. Phycol. 2011, 23, 543-597. [CrossRef] 
36. Dembisky, V.M.; Srebnik, M. Natural halogenated fatty acids: Their analogues and derivatives. Prog. Lipid Res. 2002, 41, 315-367. [CrossRef]

37. Stewart, E.K.; Beauchemin, K.A.; Dai, X.; MacAdam, J.W.; Christensen, R.G.; Villalba, J.J. Effect of tannin-containing hays on enteric methane emissions and nitrogen partitioning in beef cattle 1. J. Anim. Sci. 2019, 8, 3286-3299. [CrossRef]

38. Romero-Huelva, M.; Molina-Alcaide, E. Nutrient utilization, ruminal fermentation, microbial nitrogen flow, microbial abundances, and methane emissions in goats fed diets including tomato and cucumber waste fruits. J. Anim. Sci. 2013, 91, 914-923. [CrossRef]

39. Martínez-Fernández, G.; Abecia, L.; Arco, L.; Cantalapiedra-Hijar, G.; Martín-García, A.I.; Molina-Alcaide, E.; Kindermann, M.; Duval, S.; Yáñez-Ruiz, D.R. Effects of ethyl-3-nitrooxy propionate and 3-nitrooxypropanol on ruminal fermentation, microbial abundance, and methane emissions in sheep. J. Dairy Sci. 2014, 97, 3790-3799. [CrossRef] [PubMed]

40. Olijhoek, D.W.; Hellwing, A.L.F.; Grevsen, K.; Haveman, L.S.; Chowdhury, M.R.; Løvendahl, P.; Weisbjerg, M.R.; Noel, S.J.; Højbjerg, S.J.; Wiking, L.; et al. Effect of dried oregano (Origanum vulgare L.) plant material in feed on methane production, rumen fermentation, nutrient digestibility, and milk fatty acid composition in dairy cows. J. Dairy Sci. 2019, 102, 9902-9918. [CrossRef] [PubMed]

41. Dado, R.G.; Allen, M.S. Enhanced intake and production of cows offered ensiled alfalfa with higher neutral detergent fiber digestibility. J. Dairy Sci. 1996, 79, 418-428. [CrossRef]

42. Damborg, V.K.; Stødkilde, L.; Jensen, S.K.; Weisbjerg, M.R. Protein value and degradation characteristics of pulp fibre fractions from screw pressed grass, clover and lucerne. Feed Sci. Technol. 2018, 244, 93-103. [CrossRef]

43. Mata, G.; Masters, D.G.; Buscall, D.; Street, K.; Schlink, A.C. Responses in wool growth, liveweight, glytathione and amino acids, in Merino wethers fed increasing amounts of methionine protected from degradation in the rumen. Aust. J. Agric. Res. 1995, 46, 1189-1204. [CrossRef]

44. Hvelplund, T.; Weisbjerg, M.R. In situ techniques for the estimation of protein degradability and postrumen. Forage evaluation in ruminant nutrition. In Forage Evaluation in Ruminant Nutrition; Axford, R.F.E., Omed, H.M., Eds.; CAB International: Oxfordshire, UK, 2000; pp. 233-259.

45. Eschenlauer, S.C.P.; McKain, N.; Walker, N.D.; McEwan, N.R.; Newbold, C.J.; Wallace, R.J. Ammonia production by ruminal microorganisms and enumeration, isolation and characterization of bacteria capable of growth on peptides and amino acids from the sheep rumen. Appl. Environ. Microb. 2002, 68, 4925-4931. [CrossRef]

(C) 2020 by the authors. Licensee MDPI, Basel, Switzerland. This article is an open access article distributed under the terms and conditions of the Creative Commons Attribution (CC BY) license (http://creativecommons.org/licenses/by/4.0/). 